\title{
Oestrogen at the neonatal stage is critical for the reproductive ability of male mice as revealed by supplementation with $17 \beta$-oestradiol to aromatase gene (Cyp19) knockout mice
}

\author{
K Toda, T Okada ${ }^{1}$, K Takeda ${ }^{2}$, S Akira ${ }^{2}$, T Saibara ${ }^{3}$, M Shiraishi ${ }^{4}$, \\ S Onishi ${ }^{3}$ and $\mathbf{Y}$ Shizuta \\ Departments of Medical Chemistry, ${ }^{1}$ Anatomy and ${ }^{3}$ Internal Medicine, and ${ }^{4}$ Institute for Laboratory Animals, Kochi Medical School, Nankoku, \\ Kochi 783-8505, Japan \\ ${ }^{2}$ Department of Host Defense, Research Institute for Microbial Diseases, Osaka University, Suita, Osaka 565-0871, Japan \\ (Requests for offprints should be addressed to K Toda, Department of Medical Chemistry, Kochi Medical School, Nankoku, Kochi 783-8505, Japan; \\ Email: todak@kochi-ms.ac.jp)
}

\begin{abstract}
Aromatase P450 (CYP19) is an enzyme responsible for the conversion of androgens to oestrogens. We generated CYP19 knockout (ArKO) mice by targeted disruption of Cyp19 and studied the role of oestrogens in male reproductive ability. Approximately $85 \%$ of ArKO males were unable to sire offspring. However, no obvious difference was found in testicular and epididymal weights, numbers of sperm in the epididymis or the ability of sperm to fertilize eggs in vitro between wild-type and ArKO males. An examination of mating behaviour demonstrated that ArKO males showed an impairment in mounting
\end{abstract}

behaviour against sexually mature females. The inability of more than $90 \%$ of ArKO males to sire offspring was reversed by repeated subcutaneous injections of $17 \beta$ oestradiol when initiated on the day of birth. The effects of $17 \beta$-oestradiol on reproduction were concentration dependent and evident when supplementation was initiated on day 7, but not on day 15 after birth. These findings suggest that oestrogens acting during neonatal life are required for normal mating behaviour in adulthood.

Journal of Endocrinology (2001) 168, 455-463

\section{Introduction}

Aromatase P450 (CYP19) catalyzes the conversion of androgens to oestrogens (Simpson et al. 1994). In mice, expression of Cyp19 is found predominantly in the gonads and the brain (Yamada et al. 1993). We have previously reported the isolation of a full-length cDNA encoding mouse aromatase $\mathrm{P} 450$ and the determination of its nucleotide sequence (Terashima et al. 1991). Recent studies have demonstrated that transcription of Cyp19 is regulated by tissue-specific promoters coupled with alternative splicing events (Lephart 1996), as is the case for the human homologue (Simpson et al. 1994).

The physiological roles of oestrogens in the male have been reviewed recently (Sharpe 1998). Defects in reproductive function were frequently observed when male mice were exposed to high doses of oestrogens during the prenatal or neonatal period (McLachlan et al. 1975, Newbold et al. 1986, Toppari et al. 1996). Furthermore, studies on mice lacking one of oestrogen receptors, ER $\alpha$ $(\alpha$ ERKO), have suggested that the oestrogen/ER $\alpha$ signalling pathway is not only important for reproductive function (Eddy et al. 1996, Hess et al. 1997, Couse \&
Korach 1999), but also for male reproductive behaviour such as intromission and ejaculation (Wersinger et al. 1997, Ogawa et al. 1997, 1998).

In addition to the regulatory function of oestrogens in the reproductive system, a number of studies have clarified their roles in the central nervous system, which controls development of sexual behaviour in males. Testicular testosterone was first proposed as a regulator of male reproductive behaviour (Stone 1939, Davidson 1966). However, oestradiol has been demonstrated to mimic the effects of testosterone (Davis \& Barfield 1979, Vagell \& McGinnis 1997). Furthermore, administration of dihydrotestosterone, a non-aromatizable androgen, was ineffective in restoring male sexual behaviour in castrated rats (McDonald et al. 1970) and treatment of neonatal male rats with androst-1,4,6-triene-3,17-dione, an aromatase inhibitor, resulted in modulation of androgen-induced sexual behaviour (Christensen \& Clemens 1975, Beyer et al. 1976, Booth 1978). These studies proposed a hypothesis that, in rodents, testosterone of testicular origin is aromatized in the brain to oestradiol, which acts as the principle biologically active molecule responsible for brain sexual differentiation at the perinatal stage in the male 
(Arnold \& Gorski 1984, Lephart 1996). This stage is called the critical period. While the exact mechanisms by which oestrogens control the organization of neural networks during the critical period in the brain are not well understood, it is known that oestrogens modulate prenatal/ postnatal neuronal maturation and formation of neural circuits. These actions of oestrogens are thought to be important for the formation of sexual dimorphism observed in some parts of the brain such as the preoptic area, ventromedial hypothalamic nuclei and medial amygdala, all of which are generally recognized as sites involved in the control of sexual behaviour (McEwen et al. 1982, Arnold \& Gorski 1984, Lephart 1996, Beyer 1999).

We recently generated mice lacking aromatase (ArKO mice) by targeted disruption of Cyp 19. The female ArKO mice were totally infertile and the size of their uteri and bone density was decreased. These phenotypes are very similar to those seen in ovariectomized mice. The ArKO males showed massive accumulation of fat within the gonadal fat pads and develop hepatic steatosis with aging. Biochemical and histological studies have revealed that the hepatic steatosis is attributable, at least in part, to suppression of hepatic enzyme activities involved in fatty acid $\beta$-oxidation (Nemoto et al. 2000). Furthermore ArKO males exhibit an impairment in intermale aggressive behaviour (Toda et al. 2000, 2001). In the present study, we use ArKO male mice to clarify the physiological roles of oestrogens in male reproduction. We observed that the reproductive ability of the ArKO males was severely impaired, however, this impairment was reversed by supplementation with $17 \beta$-oestradiol $\left(E_{2}\right)$ when the treatment was initiated soon after birth.

\section{Materials and Methods}

\section{Animals}

Animal care and experiments were carried out in accordance with institutional animal care regulations. All animals were maintained on a $12 \mathrm{~h}$ light: $12 \mathrm{~h}$ darkness cycle at $22-25{ }^{\circ} \mathrm{C}$ and fed with a standard rodent chow (NMF; Oriental Yeast, Tokyo, Japan) and water ad libitum. Mice lacking functional CYP19 due to targeting disruption of Cyp19 were generated as described (Nemoto et al. 2000, Toda et al. 2000). Briefly, a targeting vector was designed based on the structure of Cyp19, in which an $87 \mathrm{bp}$ fragment, located within exon 9, corresponding to nucleotide position 1124-1210 relative to the translational start site in the mature mRNA (corresponding amino acid residues numbers 375-403) (Terashima et al. 1991), was replaced with a neomycin-resistance gene derived from pMC1-neo (Thomas \& Capecchi 1987). The deletion of the $87 \mathrm{bp}$ sequence from the gene was verified as inactivating the gene function completely by in vitro expression studies. The linearized target vector was electroporated into embryonic stem cells (E14-1) (Takeda et al. 1996).
Selected embryonic stem cells were then microinjected into C57BL/6J blastocysts to generate chimeric mice. Chimeric male mice were mated with C57BL/6J female mice to generate mice heterozygous for the mutation, which were then inter-crossed to generate mice homozygous for the Cyp19 mutation (ArKO) (Toda et al. 2000). For comparison of phenotypes, wild-type and knockout mice from the same litters were used.

\section{Expression of Cyp19}

Total RNA was prepared from testes and brains of wild-type and ArKO mice at 14 weeks of age according to the method of Mirkes (1985). One microgram of each RNA was reverse transcribed with $10 \mathrm{pmol}$ of an oligo dT primer in a final volume of $20 \mu \mathrm{l}$ using Moloney murine leukaemia virus-reverse transcriptase (Gibco-BRL, Rockville, MD, USA). Subsequent analyses with polymerase chain reaction (PCR) were carried out with $1 \mu$ of the cDNA (equivalent to $0.05 \mu \mathrm{g}$ total RNA) with a set of primers to amplify fragments containing nucleotide sequences of exons 8 and 9 of Cyp19 (expected fragment size: $284 \mathrm{bp}$ ) (sense 5'-GCAGCTCCTGACACCAT GTC-3'; antisense 5'-CTTCCGATGTTCAGAATG ATGTT-3'), exons 6 and 7 of Cyp17 (319 bp) (sense 5'-TGGTGCACAATCCTGAGGTG-3'; antisense 5'TTGGATCTAAGAAGCGCTCA-3'), and a fragment of transcripts of the glyceraldehyde-3-phosphate dehydrogenase (GAPDH) gene $(210 \mathrm{bp})$ (sense $5^{\prime}$-CGGATT TGGTCGTATTGG-3'; antisense $5^{\prime}$-TCCTGGAAG ATGGTGATG-3'). Thirty-eight cycles of $30 \mathrm{~s}$ at $94^{\circ} \mathrm{C}$, $30 \mathrm{~s}$ at $55^{\circ} \mathrm{C}$, and $1 \mathrm{~min}$ at $74{ }^{\circ} \mathrm{C}$ were used for amplification of the fragments. Portions of the products were analyzed by electrophoresis on 5\% polyacrylamide gels. Amplified fragments were verified by determination of the nucleotide sequence following subcloning into the plasmid, pBluescript II SK $(-)$.

\section{Histological examination}

Histological studies were carried out using five mice of each genotype. Testes from wild-type and ArKO mice at 14 weeks of age were fixed in 10\% buffered formalin solution for 2 days before dehydration and then embedded in paraffin. Samples were cut in sections of $5 \mu \mathrm{m}$ thickness and stained with haematoxylin and eosin. The thickness of seminiferous epithelium was measured in 30 randomly selected seminiferous tubules cross-sections at stage VII of the spermatogenic cycle for each individual. The data were analyzed statistically with the Mann-Whitney U-test. The results are expressed as the mean thickness \pm s.D.

\section{Evaluation of sperm function}

Five and nine mice were used for counting the numbers of sperm of wild-type and ArKO males at 9-16 weeks of age 
respectively. One of the two epididymides was dissected and used for counting. Sperm in each epididymis were allowed to disperse into $1 \mathrm{ml}$ phosphate-buffered saline. A 1:10 dilution was used for haemocytometric count. Three wild-type C57Bl/6J female mice at 4 weeks of age were injected with pregnant mare serum gonadotrophin (i.p. $5 \mathrm{IU} / \mathrm{mouse})$ and then given human chorionic gonadotrophin (i.p. $5 \mathrm{IU} / \mathrm{mouse}) 48 \mathrm{~h}$ later. Oocyte/cumulus masses were surgically extracted from oviducts $18 \mathrm{~h}$ after the second injection. They were then incubated for $5 \mathrm{~h}$ at $37^{\circ} \mathrm{C}$ with sperm at a concentration of $1-2 \times 10^{5}$ sperm/ $\mathrm{ml}$, derived from the wild-type or ArKO males (Hogan et al. 1994) to evaluate the ability of sperm to fertilize the eggs. In the in vitro fertilization assays, sperm were collected from both epididymides from a mouse of each genotype. We repeated this experiment three times and obtained the same results. In one experiment, we used ArKO males at 10 months of age, instead of young males.

\section{$E_{2}$ supplementation}

Oestradiol (Sigma-Aldrich, Kyoto, Japan; minimum purity $98 \%$ ) was dissolved in sesame oil. In the first group of mice, subcutaneous injections were initiated on the day of birth with the following amounts of $E_{2}$ in a volume of $25 \mu \mathrm{l}: 7 \cdot 5 \mathrm{ng}(n=10$ ArKO males), $0 \cdot 75 \mu \mathrm{g}(n=10), 1 \cdot 5 \mu \mathrm{g}$ $(n=7), 7 \cdot 5 \mu \mathrm{g}(n=16)$ and $15 \mu \mathrm{g}(n=7)$. The treatment was repeated every fourth day for 3 weeks. The ArKO mice in the control group $(n=7)$ were administered $25 \mu \mathrm{l}$ sesame oil vehicle. After 3 weeks, the mice that had been injected with $7.5 \mathrm{ng} \mathrm{E}_{2}$ from birth continued to receive once weekly injections of $7.5 \mathrm{ng} \mathrm{E}_{2}$, whilst the other experimental groups of mice were injected with $0.75 \mu \mathrm{g}$ $\mathrm{E}_{2}$ or vehicle (controls) once a week until the end of the experiments. In the second group of mice, injections of $7 \cdot 5 \mu \mathrm{g} \mathrm{E}_{2}$ were initiated from day $5(n=12)$, day $7(n=10)$ and day $15(n=12)$ after birth and administered every fourth day until the mice were 3 weeks of age after which the mice were treated with $0.75 \mu \mathrm{g} \mathrm{E}_{2}$ once a week until the end of the experiments. The third group of ArKO males $(n=11)$ was only supplemented with $7 \cdot 5 \mu \mathrm{g} \mathrm{E}_{2}$ on the day of birth and on postnatal day 4. Analysis was performed using animals at 12-24 weeks of age.

\section{Evaluation of male reproduction}

Mice at 16-20 weeks of age were used for the evaluation of reproductive ability. Each wild-type $(n=25)$ or ArKO $(n=20)$ female was mated with a wild-type or heterozygous male. Untreated ArKO $(n=28)$ and ArKO males supplemented with $\mathrm{E}_{2}$ as described (vehicle $(n=7), 7 \cdot 5 \mathrm{ng}$ $\mathrm{E}_{2}(n=10), 0 \cdot 75 \mu \mathrm{g} \mathrm{E}_{2}(n=10), 1 \cdot 5 \mu \mathrm{g} \mathrm{E}_{2}(n=7), 7 \cdot 5 \mu \mathrm{g} \mathrm{\textrm {E } _ { 2 }}$ $(n=16)$, and $15 \mu \mathrm{g} \mathrm{E}_{2}(n=7), 7 \cdot 5 \mu \mathrm{g} \mathrm{E}_{2}$ initiated on day 7 $(n=10)$, day $15(n=12)$, and days 1 and $4(n=11))$ were also used for evaluation of reproductive ability. Each male was housed with two females known to be fertile. When males did not sire litters during a continuous mating period of 2 months, they were considered to be infertile. Males that sired litters more than twice were considered to be fertile.

\section{Analysis of mounting behaviour}

Behaviour tests were performed in a standard polycarbonate mouse cage $(23 \times 16 \times 13 \mathrm{~cm})$ in a dimly lit room between 1800 and $2000 \mathrm{~h}$. Twelve wild-type and 18 ArKO males at 16-24 weeks of age were used for the analysis. Mounting behaviour was analyzed during a 30-min test with a wild-type C57BL/6J female mouse at 8 weeks of age in the home cage of the male. The females were ovariectomized and injected subcutaneously with $10 \mu \mathrm{g} \mathrm{E} \mathrm{E}_{2}$ (48 h prior to the test) and $500 \mu \mathrm{g}$ progesterone (4-6 $\mathrm{h}$ prior to the test). The number of mounts and latencies to first mount of each male were scored at least twice with a weekly interval.

\section{Statistical analysis}

Data were analyzed by Wilcoxon rank-sum test, Wilcox signed rank test, chi-square test or Mann-Whitney U-test. The differences were regarded to be significant when $P<0 \cdot 05$.

\section{Results}

We first examined the expression of CYP19 mRNA by means of RT-PCR using testicular and brain RNAs prepared from wild-type and ArKO mice. As shown in Fig. 1, the transcripts encompassing nucleotide sequence of exon 8 to exon 9 of Cyp 19 were detected in the cDNAs derived from the testicular as well as the brain RNA of the wild-type mice, but not in those of the ArKO mice. In contrast, comparable amounts of transcripts of Cyp17 and the GAPDH gene were detected in the testes and brains of both genotypes respectively. Thus, these results established that the full-length transcript of Cyp19 was absent from the testes and brains of ArKO mice.

The reproductive ability of ArKO mice was analyzed together with wild-type mice and mice heterozygous for the Cyp19 mutation (Table 1). No apparent fertility problems were observed in the wild-type and heterozygous mice. In contrast, ArKO females were totally infertile and ArKO males showed reduced reproductive ability. We observed that mice homozygous for the mutation were born with an expected ratio of the Mendelian frequency when crossed between heterozygous mice (data not shown). Histological analysis of the testes of wild-type and ArKO mice aged 14 weeks revealed that seminiferous epithelial layers in the testes of ArKO males (thickness at stage VII of the spermatogenesis cycle: 


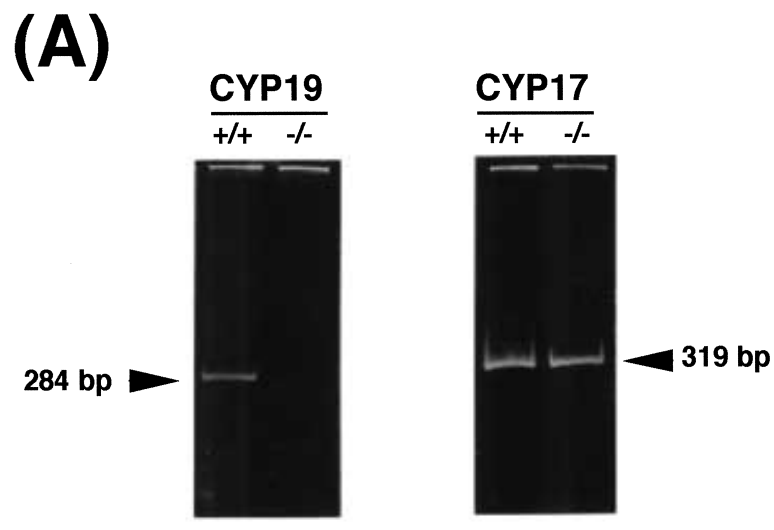

(B)

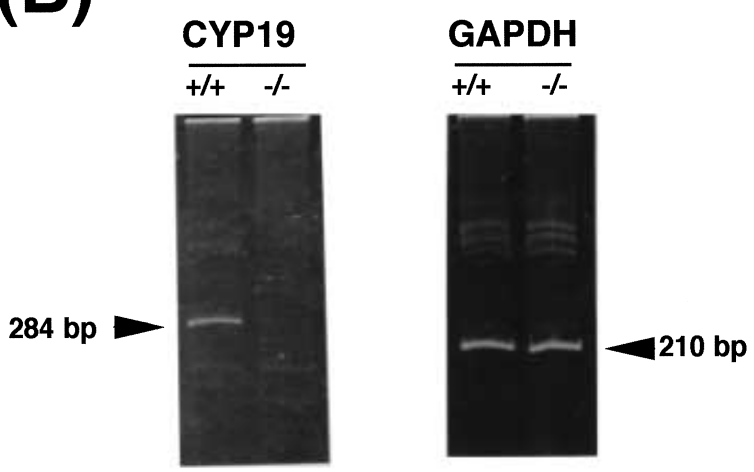

Figure 1 Expression of Cyp19 in the testes and brains. Total RNA prepared from the testes (A) or brains (B) of wild-type $(+/+)$ or ArKO ( $-/-)$ mice was reverse transcribed. A portion of cDNAs was used for PCR amplification of a fragment encompassing exon 8 to exon 9 (284 bp) of Cyp 19, exon 6 to exon 7 (319 bp) of Cyp17 or GAPDH (210 bp).

$55 \cdot 1 \pm 5 \cdot 5 \mu \mathrm{m})$ were apparently thinner than those of wild-type mice $(64 \cdot 5 \pm 4 \cdot 0 \mu \mathrm{m}, \quad P<0 \cdot 0001)$ (Fig. 2). However, we could find no gross difference in the thickness of the seminiferous epithelium at other stages of the spermatogenic cycle in the mice of each genotype

Table 1 Reproductive ability which was calculated by dividing the number of litters by the number of mice mated and expressed as $\%$ fertility

\begin{tabular}{|c|c|c|c|c|}
\hline Female & Male & $\begin{array}{l}\text { Number of } \\
\text { mice mated }\end{array}$ & $\begin{array}{l}\text { Number } \\
\text { of litters }\end{array}$ & $\%$ fertility \\
\hline$+/+$ & $+/+$ & 10 & 10 & 100 \\
\hline$+/+$ & $+1-$ & 15 & 15 & 100 \\
\hline$-1-$ & $+/+$ & 10 & 0 & 0 \\
\hline$-1-$ & $+1-$ & 10 & 0 & 0 \\
\hline$+1-$ & $+1-$ & 16 & 16 & 100 \\
\hline$+/+$ & $-1-$ & 28 & 4 & 14 \\
\hline$-1-$ & $-1-$ & 12 & 0 & 0 \\
\hline
\end{tabular}

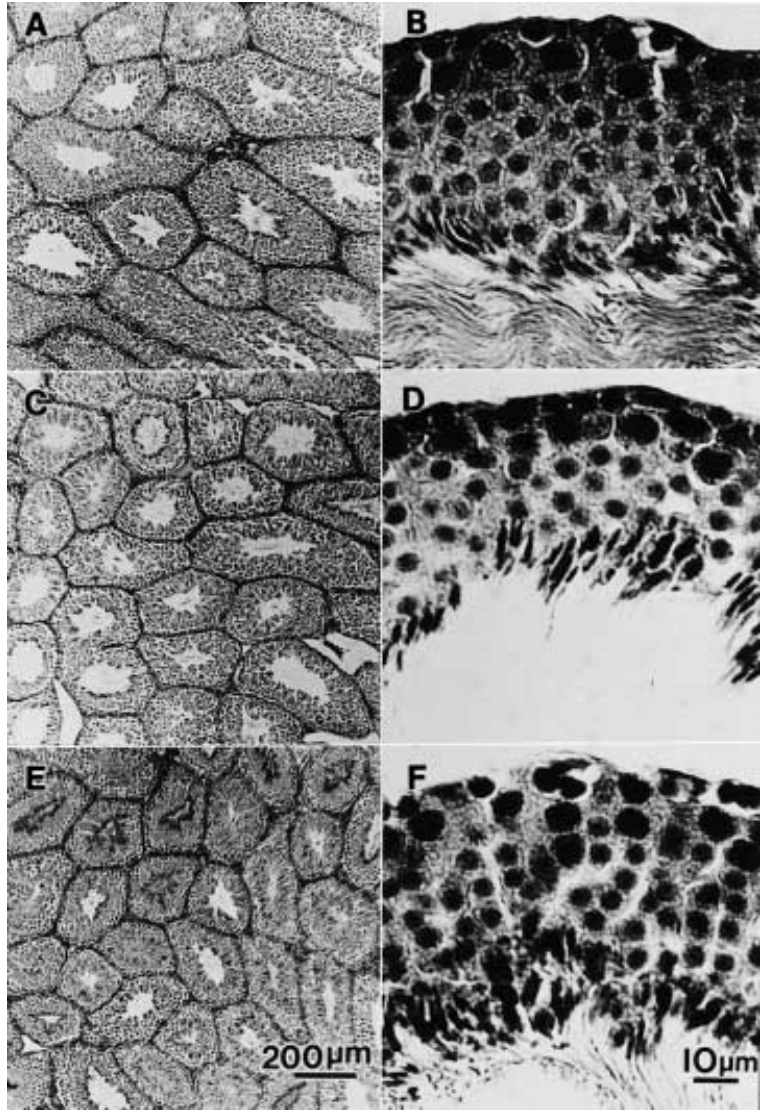

Figure 2 Testicular histology of wild-type and ArKO mice aged 14 weeks. Haematoxylin and eosin staining of the testes from a wild-type mouse (A and B), an ArKO mouse (C and D), and an ArKO mouse treated with $7.5 \mu \mathrm{g} \mathrm{E}_{2}$ /mouse on the day of birth and on every fourth day thereafter until 3 weeks of age, then the mouse was given $0.75 \mu \mathrm{g} E_{2}$ once a week ( $E$ and $F$ ). Seminiferous tubule cross-sections at stage VII of the spermatogenic cycle are shown (B, D and F). Thicknesses are (B) $64.4 \pm 4.0 \mu \mathrm{m}$, (D) $55 \cdot 1 \pm 5 \cdot 5 \mu \mathrm{m}(P<0 \cdot 001$ vs wild-type male) and (F) $65 \cdot 2 \pm 9 \cdot 6 \mu \mathrm{m}$ ( $P>0.05$ vs wild-type male). Bars: $200 \mu \mathrm{m}$ (A, C and E) and $10 \mu \mathrm{m}$ $(B, D$ and $F)$. Values are mean thickness \pm S.D.

examined $(n=5)$. Furthermore, we observed no abnormalities such as atrophic or degenerating seminiferous tubules, or dilation of the seminiferous tubule lumens which were reported in $\alpha E R K O$ mice (Eddy et al. 1996). We found no statistically significant difference in testicular and epididymal weights, or the numbers of sperm between wild-type and ArKO mice at 9-16 weeks of age as shown in Table 2. We also observed that sperm of both ArKO and wild-type males were functional and able to fertilize eggs when examined using an in vitro fertilization assay (Fig. 3). We obtained essentially the same results with ArKO males at 10 months of age in the in vitro fertilization assay as well as in the testicular histology to those of the ArKO mice aged 14 weeks (data not shown). It was concluded, therefore, that sperm are concentrated

Journal of Endocrinology (2001) 168, 455-463 
Table 2 Testicular and epididymal weights, and sperm number. One of the testes and caudae epididymides of each mouse were used to evaluate the weights and numbers of sperm respectively. Values are means \pm S.E.M.

\begin{tabular}{|c|c|c|c|}
\hline & $\begin{array}{l}\text { Testicular } \\
\text { weight }\end{array}$ & $\begin{array}{l}\text { Epididymal } \\
\text { weight }\end{array}$ & $\begin{array}{l}\text { Sperm number } \\
\text { (per epididymis) }\end{array}$ \\
\hline Wild-type & $\begin{array}{l}128 \pm 20 \cdot 2 \mathrm{mg} \\
(n=13)\end{array}$ & $\begin{array}{l}46 \cdot 2 \pm 1 \cdot 3 \mathrm{mg} \\
(n=5)\end{array}$ & $\begin{array}{l}0.9 \pm 0.06 \times 10^{7} \\
(n=5)\end{array}$ \\
\hline ArKO & $\begin{array}{l}119 \pm 17 \cdot 1 \mathrm{mg} \\
(n=15)\end{array}$ & $\begin{array}{l}44 \cdot 6 \pm 5 \cdot 2 \mathrm{mg} \\
(n=9)\end{array}$ & $\begin{array}{l}1 \cdot 2 \pm 0.6 \times 10^{7} \\
(n=9)\end{array}$ \\
\hline
\end{tabular}

normally in the epididymis of ArKO males and that their function remains unaffected.

As shown in Fig. 4, the sexual behavioural study of ArKO males revealed an impairment in mounting behaviour. Over $90 \%$ of wild-type males (11 of 12) showed mounting against ovariectomized females during the test period (30 min), whereas only 10\% (2 of 18) of the ArKO males aged 16-24 weeks showed mounting behaviour $(P<0 \cdot 0001$ vs wild-type males). Latency to first mount of wild-type males was $480 \pm 231 \mathrm{~s}$, whereas in ArKO males it extended to $670 \pm 348 \mathrm{~s}$ ( $P<0 \cdot 0001$ vs wild-type males).
To confirm the reduction of mounting frequency in ArKO males, we changed the duration of the test by extending its time in some groups to $60 \mathrm{~min}$. However, neither an increase in the number of mounts nor signs of intromission were observed in ArKO males under such modified conditions. In addition, we did not observe any plug formation during housing of ArKO males with females for 1 week $(n=7)$. These results indicated that the apparent reduction in reproduction of ArKO males was due, at least in part, to the change in mounting behaviour.

We examined the effect of $E_{2}$ supplementation on the reproductive ability of ArKO males. As shown in Fig. 5A, when $E_{2}$ was administered at a concentration of $7 \cdot 5 \mu \mathrm{g}$ / mouse, the reproductive function of ArKO males returned to the levels of wild-type mice $(P<0 \cdot 0001$ vs untreated ArKO males). The effect of $E_{2}$ was evident at a concentration of $1.5 \mu \mathrm{g} \mathrm{E}_{2} /$ mouse (6 of 7 males were fertile, $P<0.01$ vs untreated ArKO males), but only a marginal effect was observed at concentrations less than $0.75 \mu \mathrm{g}$ $\mathrm{E}_{2} /$ mouse (5 of 10 males were fertile, $P>0 \cdot 05$ vs untreated ArKO males). When supplementation was initiated on day 7 after birth, $\mathrm{E}_{2}$ was also able to support reproduction in ArKO males $(P<0 \cdot 0002$ vs untreated ArKO males) (Fig. 5B). However, when it was initiated on day 15 after
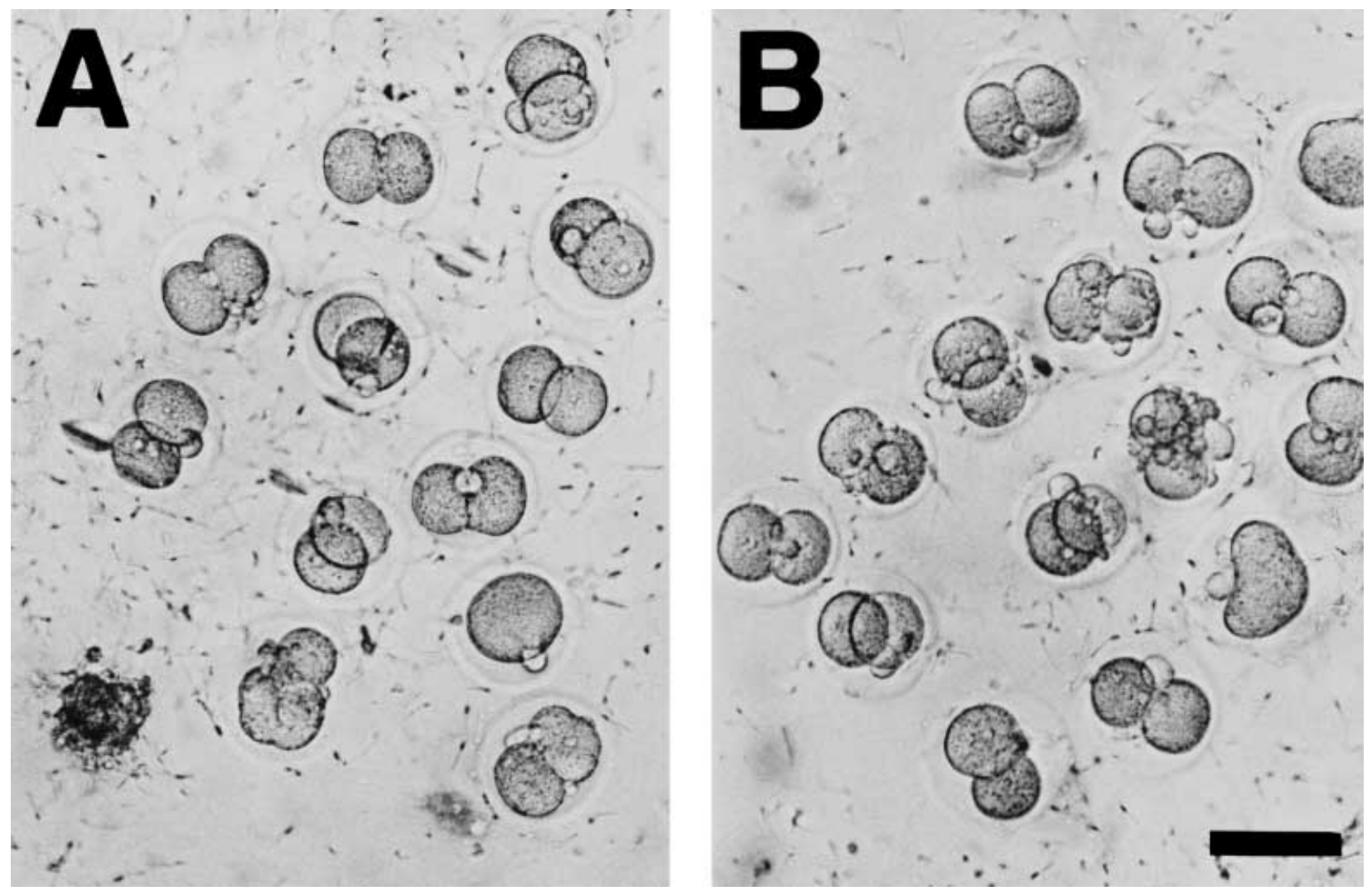

Figure 3 Fertilization with sperm from wild-type and ArKO mice in vitro. Eggs of wild-type females were mixed with sperm of wild-type (A) or ArKO (B) mice and incubated at $37^{\circ} \mathrm{C}$ for $1 \mathrm{~h}$. Note that after $1 \mathrm{~h}$, polar bodies were observed equally in both cases. Bar: $100 \mu \mathrm{m}$. 


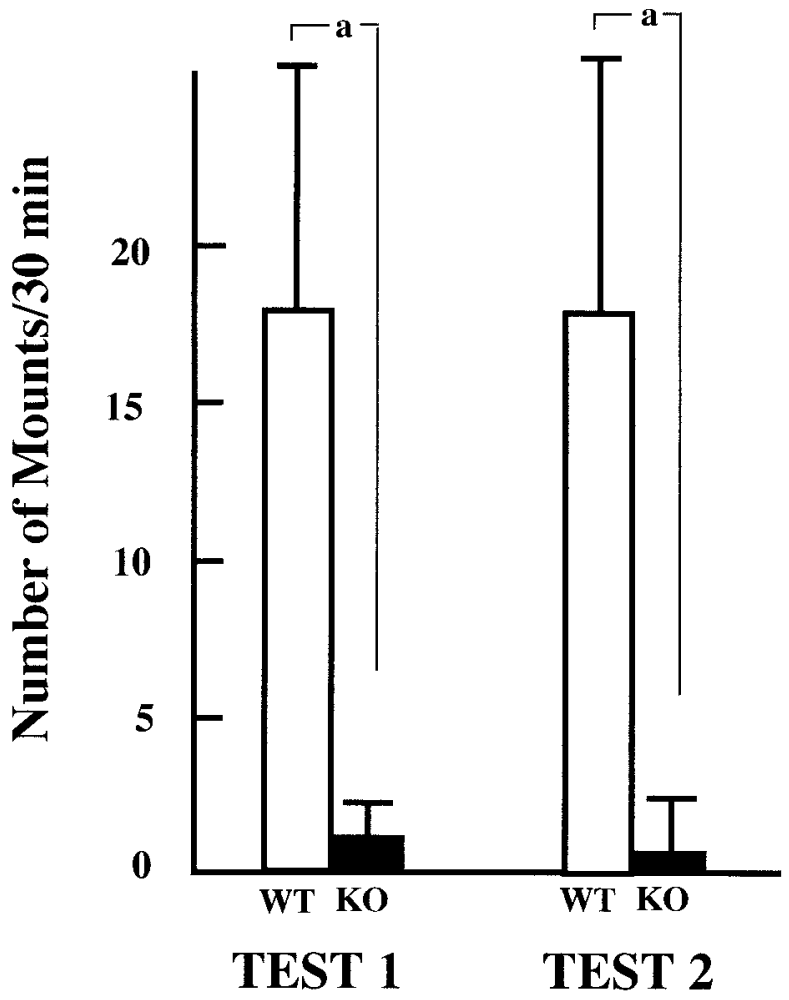

Figure 4 Impairment of mounting behaviour in ArKO males. Mounting behaviour was examined by counting the number of mounts performed by each mouse against a sexually mature female mouse during the test period of $30 \mathrm{~min}$. The mean numbers of mount per wild-type $(n=12)$ and ArKO $(n=18)$ mouse are shown as open and solid bars respectively. Vertical bars represent S.E.M. a, $P<0 \cdot 0001$.

birth, the effects of $\mathrm{E}_{2}$ were negligible $(P>0 \cdot 05 \mathrm{vs}$ untreated ArKO males). In contrast, $80 \%$ of ArKO males ( 9 of 11) given $E_{2}$ on the day of birth and on postnatal day 4 were fertile, although only four mice were able to sire offspring more than twice. Histological analysis demonstrated that supplementation with $7 \cdot 5 \mu \mathrm{g} \mathrm{E}_{2}$ /mouse resulted in an increased thickness of seminiferous epithelial layers compared with that in the untreated ArKO males $(65 \cdot 2 \pm 9 \cdot 6 \mu \mathrm{m})$ (Fig. $2 \mathrm{E}$ and $\mathrm{F}, P<0 \cdot 0001$ vs untreated ArKO males).

\section{Discussion}

We generated ArKO mice in which an $87 \mathrm{bp}$ fragment in exon 9 of Cyp19 was replaced with the neomycinresistance gene to disrupt the gene function. Until now, three kinds of ArKO mice have been generated independently. These characteristic phenotypes are presented in Table 3. On the whole, the phenotypes of these mice appear to be similar; however, differences have been

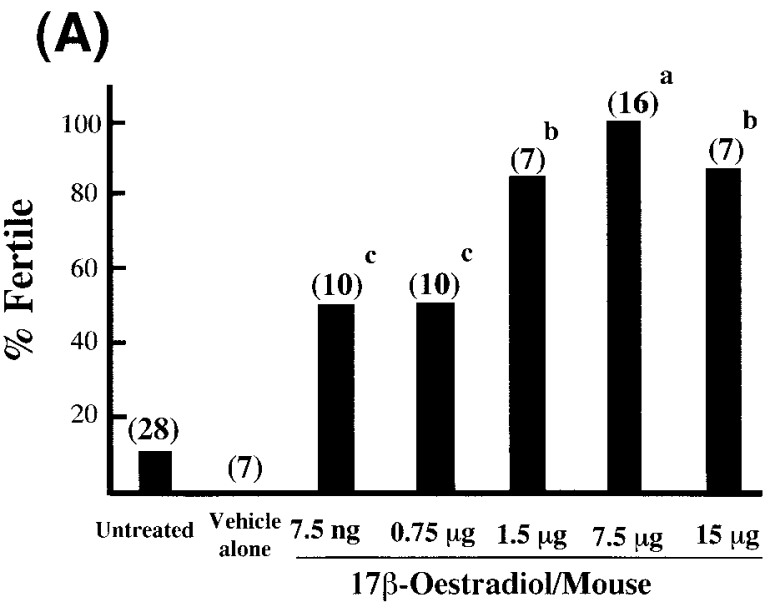

(B)

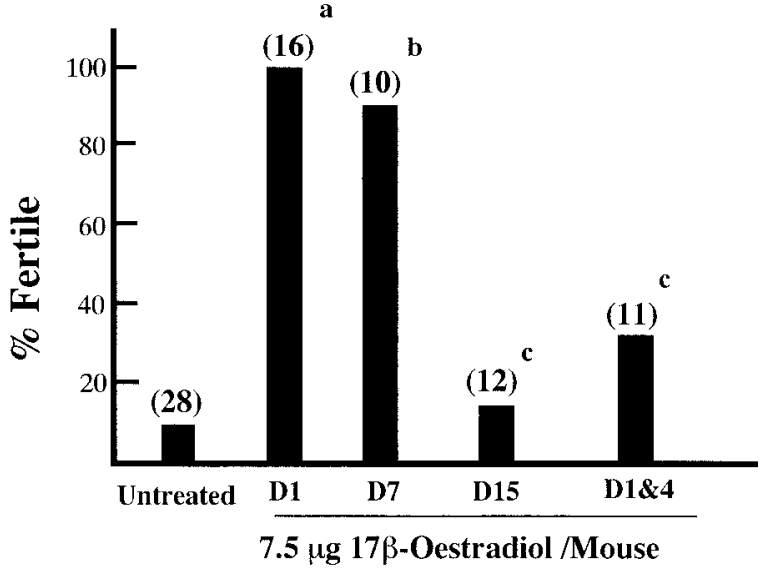

Figure 5 Reversal of the impairment in reproductive ability of ArKO males with $E_{2}$ supplementation. (A) Dose-dependent reversal of the reduced reproductive ability of ArKO males. Mice (numbers shown in parentheses) were supplemented with various amounts of $E_{2}$ as indicated on the day of birth. The supplementation was repeated every fourth day until day 21 , and then followed by weekly injections of $0.75 \mu \mathrm{g} \mathrm{E}_{2}$ /mouse until the end of the experiments, except for the mice given $7.5 \mathrm{ng} \mathrm{E}_{2}$, which received weekly injection of $7.5 \mathrm{ng} \mathrm{E}_{2}$ after day 21 until the end of the experiments. Vehicle alone indicates a group of ArKO males injected with $25 \mu \mathrm{l}$ sesame oil in the same fashion. Untreated indicates a group of ArKO males that did not receive any injection. a, $P<0.0001 ; b, P<0.01 ; c, P>0.05$ vs untreated ArKO males. (B) Existence of sensitive periods for reversal of the reduced reproductive ability by $\mathrm{E}_{2}$. ArKO mice were supplemented with $7.5 \mu \mathrm{g} \mathrm{E}_{2}$ on the day after birth as indicated (D1, D7, D15 and D1\&4). The supplementation was then repeated as above. D1\&4 indicates ArKO males treated with $7 \cdot 5 \mu \mathrm{g} E_{2}$ only on the day of birth and on postnatal day 4 . When these mice were 16-20 weeks of age, they were housed with wild-type females. The ArKO males supplemented with $E_{2}$ from day 1 are the same mice as those described in (A). The numbers in parentheses indicate the number of mice examined. Improvement of reduced reproductive ability of ArKO males was calculated by dividing the number of mice siring litters more than twice with the total number of mice examined and expressed as \% fertility. a, $P<0.0001 ; b, P<0.0002 ; c, P>0 \cdot 05$ vs untreated ArKO males. 
Table 3 Comparison of phenotypes of ArKO mice generated

\section{Fisher et al.}

Disrupted sites in the gene

Name of ES cells used (mouse strain from which the ES cells are derived)

Host blastocyst

External phenotype

Accumulation of abdominal fat

Fertility

Female

Male

Behaviour

References

\section{Exon IX}

KG $(129 /$ sv $)$

C57BL/6J

Coats are dull at 3 weeks of age;

No development of labial folds in the females

Yes

Infertile

Fertile until 14 weeks of age, but infertile at 7 months of age $(n=3)$

Spermatogenesis:

At 12-14 weeks of age; normal

At 4.5 months of age; 3 of 4 are normal and one has no sperm

At 1 year of age; a general reduction in the number of sperm in the cauda epididymis

N.D.

Fisher et al. (1998)

Robertson et al. (1999)
Honda et al.

Exon I and II

CCE $(129 /$ sv $)$

C57BL/6

Indistinguishable from wild-type

Yes

Infertile

1 out of 10 mice is fertile

(14-17 weeks of age)

Spermatogenesis:

At 12-16 weeks of age; active sperm in the testis and epididymis
Toda et al.

Exon IX

E14-1 (129/sv)

C57BL/6J

Indistinguishable from wild-type

Yes

Infertile

4 out of 28 mice are fertile (10-18 weeks of age)

Spermatogenesis: At 9-16 weeks of age; normal in the number and function in the cauda epididymis $(n=9)$
Reduction of mounting behaviour against females

Honda et al. (1998)
Reduction of mounting behaviour against females

This study

N.D., not described; ES cells, embryonic stem cells.

reported with respect to male reproductive ability. The reason for these differences is not clear. As suggested previously (Robertson et al. 1999), the difference in composition of the diet might be one of the reasons. Not all ArKO males generated by us and by others (Honda et al. 1998) are infertile. This heterogeneous phenotype is also unaccountable at the moment. Oestrogens supplied maternally during gestational as well as lactational periods are possible sources that might affect the development of the male reproductive system, especially in the case of pups unable to synthesize oestrogens by themselves. In addition, oestrogens produced by wild-type or heterozygous littermates might also influence ArKO males in utero. Another possibility which may explain the differences in male reproductive function between the various ArKO models is the potential for compensation for the lack of $E_{2}$ by other steroid metabolites. It was reported that some of the ArKO mice had elevated testosterone and androstenedione levels (Fisher et al. 1998, Robertson et al. 1999). Elevation in serum testosterone levels in ArKO male aged 12-20 weeks was also observed in the present study $(2 \cdot 63 \pm 0 \cdot 7 \mathrm{ng} / \mathrm{ml}$ for wild-type males $(n=5)$ and $5 \cdot 0 \pm 1 \cdot 2 \mathrm{ng} / \mathrm{ml}$ for ArKO males $(n=5)$, means \pm S.D.).

In the present study, we have demonstrated that the suppression of normal mating behaviour in male ArKO mice can be ameliorated by $\mathrm{E}_{2}$ supplementation when it is initiated within 7 days after birth. The histological study on the testes of ArKO males revealed that $\mathrm{E}_{2}$ supplementation resulted in an increase in the thickness of seminiferous epithelial cell layers in ArKO mice. The effects of oestrogens on the seminiferous epithelium were recently reported using a hypogonadal mouse, in which oestrogen was shown to increase the total volume of the seminiferous epithelium as well as the total seminiferous tubule volume in addition to the induction of spermatogenesis (Ebling et al. 2000). Furthermore, $\mathrm{E}_{2}$ at physiological concentrations has been demonstrated to effectively inhibit apoptosis of human testicular germ cells in vitro (Pentikäinen et al. 2000). Additional evidence supporting the relative importance of oestrogenic actions in the testis was obtained from the studies on $\alpha E R K O$ mice, which showed a defect in spermatogenesis caused, in part, by 
impaired fluid reabsorption in the efferent ductules (Eddy et al. 1996, Hess et al. 1997). Nevertheless, in the present study, the disruption of Cyp19 did not result in any obvious alteration of testicular function. In addition, atrophy of the seminiferous epithelium in the testes of ArKO mice aged up to 14 weeks was not observed in this study or in a previous study (Robertson et al. 1999) as was reported in $\alpha E R K O$ mice. These findings suggest that $\mathrm{ER} \alpha$ regulates the expression of some genes which are essential for testicular function in an oestrogenindependent manner or that oestrogens or oestrogenic ligands are produced by some unidentified gene products other than Cyp19 in ArKO mice as suggested by the study on $\alpha \beta E R K O$ mice (Couse et al. 1999).

Whilst testicular function appeared normal in the ArKO males, a severe impairment in sexual behaviour was observed when mounting behaviour against sexually mature females was examined. This is consistent with a study reported recently (Honda et al. 1998). Thus, the normal development of the nervous system, which is known to be sensitive to oestrogen during neonatal life (Arnold \& Gorski 1984, Lephart 1996), is critical for male reproduction. Whilst the $\mathrm{E}_{2}$ supplementation reversed the inability of ArKO males to achieve impregnation, only marginal effects of the treatment were observed on the mounting behaviour of ArKO males when examined under experimental conditions employed (data not shown). These observations might imply that we need to supplement ArKO mice with $\mathrm{E}_{2}$ during the prenatal stage to reverse sexual behaviour, because the highest aromatase activity in the brain is observed 2 to 3 days before birth in rodents (Lephart 1996).

Studies on the sexual behaviour of $\alpha$ ERKO males have demonstrated that the males showed normal mounting behaviour but were impaired in the induction of ejaculation (Couse \& Korach 1999). This suggests that $E_{2}$ is required for mounting behaviour in an ER $\alpha$-independent manner. Nevertheless, the present findings support the view that oestrogens are required during the perinatal period (critical period) to irreversibly organize the neural circuits essential for control of reproductive activity in males.

In conclusion, the ArKO mouse model is a useful tool with which to study the molecular nature of the critical period during which oestrogens regulate the formation of neural circuitry related to the control of sexual behaviour.

\section{Acknowledgements}

This work was supported in part by research grants provided by the Ono Medical Research Foundation, and Toyota High-Tech Research Grant Program (to K T).

\section{References}

Arnold AP \& Gorski RA 1984 Gonadal steroid induction of structural sex differences in the central nervous system. Annual Review of Neuroscience 7 413-442.
Beyer C 1999 Estrogen and the developing mammalian brain. Anatomy and Embryology 199 379-390.

Beyer C, Morali G, Naftolin F, Larsson K \& Perez-Palacios 1976 Effects of some antiestrogens and aromatase inhibitors on androgen induced sexual behavior in castrated male rats. Hormones and Behavior 7 353-363.

Booth JE 1978 Effects of the aromatization inhibitor androst-4-ene3,6,17-trione on sexual differentiation induced by testosterone in the neonatally castrated rat. Journal of Endocrinology 79 69-76.

Christensen LW \& Clemens LG 1975 Blockade of testosteroneinduced mounting behavior in the male rat with intracranial application of the aromatase inhibitor androst-1,4,6-triene3,17-dione. Endocrinology 97 1545-1551.

Couse JF \& Korach KS 1999 Estrogen receptor null mice: What have we learned and where will they lead us? Endocrine Reviews $\mathbf{2 0}$ $358-417$.

Couse JF, Hewitt SC, Bunch DO, Sar M, Walker VR, Davis BJ \& Korach KS 1999 Postnatal sex reversal of the ovaries in mice lacking estrogen receptors $\alpha$ and $\beta$. Science 286 2328-2331.

Davidson JM 1966 Activation of male rat's sexual behavior by intracerebral implantation of androgen. Endocrinology 79 783-794.

Davis PG \& Barfield RJ 1979 Activation of masculine sexual behaviour by intracranial estradiol benzoate implants in male rats. Neuroendocrinology 28 217-227.

Ebling FJP, Brooks AN, Cronin AS, Ford H \& Kerr JB 2000 Estrogenic induction of spermatogenesis in the hypogonadal mouse. Endocrinology 141 2861-2869.

Eddy EM, Washburn TF, Bunch DO, Goulding EH, Gladen BC, Lubahn DB \& Korach KS 1996 Targeting disruption of the estrogen receptor gene in male mice causes alternation of spermatogenesis and infertility. Endocrinology 137 4796-4805.

Fisher CR, Graves KH, Parlow AF \& Simpson ER 1998 Characterization of mice deficient in aromatase (ArKO) because of targeted disruption of the cyp 19 gene. PNAS 95 6965-6970.

Hess RA, Bunick D, Lee K-H, Bahr J, Taylor JA, Korach KS \& Lubahn DB 1997 A role for oestrogens in the male reproductive system. Nature 390 509-512.

Hogan B, Beddington R, Costantini F \& Lacy E 1994 Manipulating the mouse embryo. A Laboratory Manual, edn 2. Cold Harbor: Cold Harbor Laboratory Press.

Honda S, Harada N, Ito S, Takagi Y \& Maeda S 1998 Disruption of sexual behaviour in male aromatase-deficient mice lacking exons 1 and 2 of the cyp 19 gene. Biochemical and Biophysical Research Communications 252 445-449.

Lephart ED 1996 A review of brain aromatase cytochrome P450. Brain Research Reviews 22 1-26.

McDonald P, Beyer C, Newton F, Brien B, Baker R, Tan HS, Sampson C, Kitching P, Greenhill R \& Pritchard D 1970 Failure of $5 \alpha$-dihydrotestosterone to initiate sexual behaviour in the castrated male rat. Nature 227 964-965.

McEwen BS, Biegon A, Davis PG, Krey LC, Luine VN, McGinnis MY, Paden CM, Parsons B \& Rainbow TC 1982 Steroid hormones: humoral signals which alter brain cell properties and functions. Recent Progress in Hormone Research 38 41-92.

McLachlan JA, Newbold RR \& Bullock B 1975 Reproductive tract lesions in male mice exposed prenatally to diethylstilbestrol. Science 190 991-992.

Mirkes PE 1985 Simultaneous banding of rat embryo DNA, RNA, and protein in cesium trifluoroacetate gradients. Analytical Biochemistry 148 376-383.

Nemoto Y, Toda K, Ono M, Fujikawa-Adachi K, Saibara T, Onishi S, Enzan H, Okada T \& Shizuta Y 2000 Altered expression of fatty acid-metabolizing enzymes in aromatase-deficient mice. Journal of Clinical Investigation 105 1819-1825.

Newbold RR, Bullock BC \& McLachlan JA 1986 Adenocarcinoma of the rete testis: diethylstilbestrol-induced lesions of the mouse rete testis. American Journal of Pathology 125 625-628. 
Ogawa S, Lubahn DB, Korach KS \& Phaff DW 1997 Behavioral effects of estrogen receptor gene disruption in male mice. PNAS 94 1476-1481.

Ogawa S, Washburn TF, Taylor J, Lubahn DB, Korach KS \& Phaff DW 1998 Modifications of testosterone-dependent behaviors by estrogen receptor - a gene disruption in male mice. Endocrinology $1395058-5069$.

Pentikäinen V, Erkkilä K, Soumalainen L, Parvinen M \& Dunkel L 2000 Estradiol acts as a germ cell survival factor in the human testis in vitro. Journal of Clinical Endocrinology and Metabolism $\mathbf{8 5}$ 2057-2067.

Robertson KM, O'Donnell L, Jones MEE, Meachem JS, Boon WC, Fisher CR, Graves KI, McLachlan RI \& Simpson ER 1999 Impairment of spermatogenesis in mice lacking a functional aromatase (cyp 19) gene. PNAS 96 7986-7991.

Sharpe RM 1998 The roles of oestrogen in the male. Trends in Endocrinology and Metabolism 9 371-377.

Simpson ER, Mahendroo MS, Means GD, Kilgore MW, Hinshelwood MM, Graham-Lorence S, Amarneh B, Ito Y, Fisher CR, Michael MD, Mendelson CR \& Bulun SE 1994 Aromatase cytochrome P450, the enzyme responsible for estrogen biosynthesis. Endocrine Reviews 15 342-355.

Stone CP 1939 Copulatory activity in adult male rat following castration and injection of testosterone propionate. Endocrinology 24 165-174.

Takeda K, Tanaka T, Shi W, Matsumoto M, Minami M, Kashiwamura S, Nakanishi K, Yoshida N, Kishimoto T \& Akira S 1996 Essential role of Stat 6 in IL-4 signalling. Nature 380 627-630.

Terashima M, Toda K, Kawamoto T, Kuribayashi I, Ogawa Y, Maeda T \& Shizuta Y 1991 Isolation of a full-length cDNA encoding mouse aromatase P450. Archives of Biochemistry and Biophysics 285 231-237.
Thomas KR \& Capecchi MR 1987 Site-directed mutagenesis by gene targeting in mouse embryo-derived stem cells. Cell 51 503-512.

Toda K, Okada S, Nakamura K, Nishihara M, Yokotani K \& Shizuta Y 2000 Concentrations of monoamines and acetylcholine in the brains of mice lacking the aromatase cytochrome P450 gene. In Molecular Steroidgenesis, Frontiers Science Series No. 29, pp 141-143. Eds M Okamoto, Y Ishimura \& H Newada. Tokyo: Universal Academic Press Inc.

Toda K, Saibara T, Okada T, Onishi S \& Shizuta Y 2001 A loss of aggressive behaviour and its reinstatement by oestrogen in mice lacking the aromatase (CYP19) gene. Journal of Endocrinology 168 217-220.

Toppari J, Larsen JC, Christiansen P, Giwercman A, Grandjean P, Guillette LJ Jr, Juegou B, Jensen TK, Jouannet P, Keiding N, Leffers H, McLachlan JA, Meyer O, Mueller J, DeMeyts ER, Scheike T, Sharpe R, Sumpter J \& Skakkebaek NE 1996 Male reproductive health and environmental xenoestrogens. Environmental Health Perspectives 104 741-803.

Vagell ME \& McGinnis MY 1997 The roles of aromatization in the restoration of male rat reproductive behavior. Journal of Neuroendocrinology 9 415-421.

Wersinger SR, Sannen K, Villalba C, Lubahn DB, Rissman EF \& De Vries GJ 1997 Masculine sexual behaviour is disrupted in male and female mice lacking a functional estrogen receptor $\alpha$ gene. Hormones and Behavior 32 176-183.

Yamada K, Harada N, Tamaru M \& Takagi Y 1993 Effects of changes in gonadal hormones on the amount of aromatase messenger RNA in mouse brain diencephalon. Biochemical and Biophysical Research Communications 195 462-468.

Received 3 October 2000

Accepted 10 November 2000 